Student Success

ISSN: 2205-0795

Volume 10, Issue 1, pp. 141-146

March 2019

\title{
The effects on student retention by implementing contextualised, program-specific learning modules in an online student success course. A Practice Report
}

\section{Jaime J. McLeod}

Sandhills Community College, Pinehurst, United States

\section{Abstract}

This practice report examines the results of inserting program-specific, contextualised modules and instructors into an online student success course in a two-year college environment. The results of multiple semesters of pre-contextualised instruction (Northern Hemisphere Spring and Fall 2015) and post-contextualisation instruction (Northern Hemisphere Fall 2016 and Spring 2017), showed an increase in next semester retention. Additionally, ten student success course instructors were interviewed to determine critical elements of the course. Instructors revealed that time management, stress management, and program-specific assignments were the most beneficial components of the course.

Please cite this article as:

McLeod, J.J. (2019). The effects on student retention by implementing contextualised, program-specific learning modules in an online student success course. A Practice Report. Student Success, 10(1), 141-146. doi: 10.5204/ssj.v10i1.1095

This practice report has been accepted for publication in Student Success. Please see the Editorial Policies under the 'About' section of the Journal website for further information.

Student Success: A journal exploring the experiences of students in tertiary education

(9) $\stackrel{0}{(1)}$ This work is licensed under a Creative Commons Attribution 4.0 International Licence. As an open access journal, articles are free to use, with proper attribution. ISSN: 2205-0795 
The effects on student retention by implementing contextualised, program-specific learning modules in an online student success course. A Practice Report

\section{Introduction}

Retention remains a problem at two-year institutions in the United States. One of the most important statistical figures reflecting this challenge is student completion rates. Completion rates at two-year institutions are a meager $27 \%$ six years after the student first enrolls at an institution (Shapiro et al., 2017). Zalaznick (2016) surveyed 100 campus officials and found $84 \%$ named student success initiatives as a top four priority at their institution. Over $90 \%$ of the educational administrators interviewed placed retention efforts as one of the most crucial initiatives (Zalaznick, 2016). There are many ways colleges retain students, but courses that focus on students in their first year of college are particularly effective. Student success courses offer an opportunity for institutions to help prepare students for the long road ahead through classroom instruction. One of the driving forces behind student success courses is retaining students (Barefoot, 2004). A foundational goal of retaining students makes these courses an excellent vehicle to help promote student academic completion.

It is vital for educational institutions and instructors to assist students in understanding the meaning of their college courses. Individuals perform poorly when a task has no meaning to them (Dewey, 1916). Contextualised learning is one practice instructors can use to assist students in seeing value in a course (Tinto, 2017). This practice report observed the results of comparing an online student success course delivered using two separate instructional methods. Study participants included 511 students using the prior instructional method and 454 using the redesigned method. Each student was enrolled at Sandhills Community College which is a public, two-year college located in Pinehurst, North Carolina (United States).
The first method taught 16 modules on basic skills and college orientation information utilising general instructors who did not teach courses in the students' major. The second redesigned method reduced the amount of generalised basic college skills and information to 10 modules and added six modules specifically tailored to the students' major. The redesigned method also replaced the instructor with a teacher in the students' major of choice. Students then enrolled in specific course sections based on their chosen major. The purpose of the curriculum change was to increase student interest in the course and help promote better retention of students in future semesters.

\section{Literature Review}

Decades of research and educational literature show student success courses can improve college student retention (Hankin, 1996; Kimbark, Peters, \& Richardson, 2017; Stupka, 1994). Student success courses target new college students. These first-year courses inform students about crucial college information, help students plan for academic and career decisions, and develop habits of a high performing student (O'Gara, Karp, \& Hughes, 2009). In the research literature, some researchers define success in a student success course by demonstrating improved retention rates for students (Hoops \& Artip, 2016). Firstyear seminar researcher Betsy Barefoot highlighted the need to study how student success courses are constructed and taught to students. First-year courses vary by institution, however, all student success courses seek to improve student retention (Barefoot, 2004).

Best practices in first year experience initiatives include programs that promote: active learning (Eckton \& Palfreyman, 2017); instruction in critical college study skills (Kimbark et. al, 2017); effective time management and stress management techniques (Crisp \& Taggart, 2013); effective relationships between students 
and teachers, awareness of the college environment (Tinto, 2012); a sense of belonging, self-efficacy, the courses' value to the student, course contextualisation (Tinto, 2017), and; institutional expectations (Karp \& Bork, 2014).

Contextualised learning is a method of delivering instruction that makes the students' learning experience more relevant to a students' everyday life and aides them in seeing the relevance of the course material (Johnson, 2002). Instructional material implementing contextualisation has shown the ability to improve retention. Karp, Raufman, Efthimiou, and Ritze (2017) observed a 10\% increase in one semester and one-year retention rates for students attending a redesigned student success course. The researchers interviewed 10 faculty members who taught a redesigned student success course and found part of the courses' success was due to the contextualised learning provided in the instruction (Karp et al., 2017). Wisely (2009) observed a higher retention rate of students in contextualised developmental math courses when compared to a traditional method of instruction.

\section{Contextualised student success course}

The previous instructional method delivered the success course in 16 modules focusing on basic college skills and introducing students to important college information. Instructors outside the students' chosen major taught each section. The assessments focused on a student quiz that tested students on information they read in the modules.

For the redesign method, the success course was adjusted to include 10 modules on college information and basic skills and six programspecific modules. The program-specific modules contained assignments that allow students to explore their major and learn more about specific industries and future careers opportunities. Program instructors were assigned specific sections and students enrolled in the sections which focused on the academic department the student selected. Specific academic departments designed each section program modules and these varied by each course section. Instructors created the modules and assessments themselves and an instructional designer was available to assist them if requested. The 10 modules covering general student success course material were consistent across all course sections.

Before the course redesign, students had responded to course surveys voicing their confusion regarding the value of the course. Some students thought the course was a waste of time and did not understand why they had to take the course. The redesigned modules provide program instructors the opportunity to teach student basic college skills while also preparing them for their future courses in the program. By creating a link from the student success course to future courses, students can clearly identify the value behind the first-year success course.

The new contextual assignments were set up to be more engaging and required the students to dig deeper into their chosen fields. Some assignments required the student to interview industry professionals while other assignments asked students to explore and research organisations that are prevalent in a specific job field. A common theme among the assignments was a focus on developing students' knowledge of their field through exploration.

\section{Methods}

The student success course detailed in this practice report served community college students with a declared, two-year, program major. Some of these majors included Nursing, Automotive, Cosmetology, Computer Technologies, Early Childhood Education and 
The effects on student retention by implementing contextualised, program-specific learning modules in an online student success course. A Practice Report

Civil Engineering. Students enrolled in sections based on their major.

Two pre-contextualised semesters were selected (Spring 2015, Fall 2015) along with two contextualised semesters (Fall 2016, Spring 2017). Spring semesters began in January and ended in May. Fall semesters began in August and ended in December. The student success course selected for this study targets applied science students who are generally not seeking to transfer to a four-year university. All course sections used in this study were taught using an online delivery method and a 16-week semester length. The study measured retention as nextsemester retention excluding summer. This means that students must return to studies in the next Spring semester when studying in the Fall semester and then return in the Fall semester when studying in the Spring semester to count as retained. Student retention data collected for the previous method included Spring 2015 to Fall 2015, Fall 2015 to Spring 2016, and for the redesigned method Fall 2016 to Spring 2017 and Spring 2017 to Fall 2017. The independent variables were the semesters (Spring 2015, Spring 2017, Fall 2015, and Fall 2016). The dependent variables were retained (student return next semester Fall/Spring) or not retained (student did not return next semester Fall/Spring). A chi-squared test was run to compare semester-to-semester retention data. Spring 2016 was eliminated due to the eight week, mini-semester format of the student success courses. Ten success course instructors at the institution were interviewed to identify the most beneficial components.

\section{Results}

A chi-square test was done comparing Fall 2015 group retention and Fall 2016 group retention of student success course students. The sample size was 319 students for Fall 2015 and 245 students for Fall 2016. The results produced a chi statistic of 8.128, with 1 degree of freedom (df) and a p-value of .004 (<.05). The effect size
(Phi) was .12. The findings show a statistically significant increase in student retention after the course redesign (Fall 2016). Students in the redesign courses were retained in the next semester at a rate of $84.5 \%$ compared to $74.6 \%$ in the prior method.

An additional chi-square test was done comparing Spring 2015 group retention and Spring 2017 group retention of student success course students. The sample size was 192 students for Spring 2015 students and 209 students for Spring 2017. The results produced a chi statistic of 6.298, with 1 degree of freed om (df) and a p-value of.012 (<.05). The effect size (Phi) was .125. The findings show a statistically significant increase in student retention after the course redesign (Spring 2017). Students in the redesign courses were retained in the next semester at a rate of $70.8 \%$ compared to $58.9 \%$ in the prior method.

Instructors teaching the redesigned sections were interviewed to obtain their perspective on the instructional change. Each faculty member responded with a more favourable opinion of the program-specific instruction and the contextualised modules. One instructor noted the role that their expertise played in aiding students, "I can answer questions that people in other departments cannot answer." Instructors in a student's chosen major had the benefit of answering questions that directly impact students most important interests.

Some instructors believed the redesign helped to make the entire course more contextualised. One instructor highlighted how they were able to further enhance students' awareness of financial aid by including information on scholarships that are only available to their program's students. Another instructor highlighted the advantage of enrolling students of the same major in a success course:

I think being in a class with only other students in your major, or group of majors, 
and taught by someone in that department, helps you feel more connected to the college. I think you're more likely to come talk to the instructor that's in your program as opposed to just some person that teaches something that you don't really know much about. I think it really helps to build connections between the students and the college.

In addition to building early connections, one instructor described how the course helped them identify potential problems adding, "I'm able to catch problems before they develop into larger ones." Instructors observed an increased ability to understand students better before they enter their major courses. The new method delivers the advantage of giving program instructors early access to their future students. Some instructors even mentioned wanting more modules for the program-specific material.

Interviewees identified course modules that assisted their students the most. Modules that gave students tips on how to manage stress and time frequently appeared in the interview transcripts. Instructors felt that their students had busy lives with numerous external distractions. Each module addressing these external factors were extremely beneficial according to the interviewees. The third most beneficial component was the program-specific, contextualised modules which received praise from the instructors. The added modules allowed students to learn about programspecific scholarships, industry jobs, and precise program expectations for graduating with a degree in their major. Helpful assignments in the six program-specific modules included interviewing industry workers, exploring job search engine sites, and learning more about organisations in the industry.

\section{Discussion and summary}

The findings from this research indicate a measurable benefit to next-semester retention through course instructor and content contextualisation. Inserting the contextualised course modules and changing to programspecific instructors resulted in a measurable improvement in a vital student success indicator. Course instructors provided positive opinions on the course changes. The instructional course revision gave instructors earlier access to their students which helped improve student to instructor connections. Every instructor interviewed felt the student success course should continue to utilise the revised method. Karp et al. (2017) observed a similar increase in retention when using contextualised course material in a success course.

These early results make a case for continuing the initiative. The notable increase in retention also provides some evidence for the effectiveness of a broader delivery of contextualised courses in higher education particularly in a student's first year of college. Contextualisation in student success courses provides an excellent opportunity to assist students in linking the course to their future careers and courses. Wisely (2009) described a prevalence of contextualisation in developmental education; however, the early findings in this practice report point to a potential use beyond basic skills and developmental education.

Curriculum faculty members interviewed in this study were eager to participate in the student success course. There was no noted resistance found in this report from program instructors regarding the teaching of a student success course. Each instructor interviewed expressed positive feelings towards the initiative and wanted to continue delivering the student success curriculum to their students. Some instructors felt the course needed more of the program-specific modules. Bringing contextualisation into the first-year experience through integrating program-specific instructors into the curriculum could 
The effects on student retention by implementing contextualised, program-specific learning modules in an online student success course. A Practice Report

potentially foster a better relationship between students and their future instructors.

\section{References}

Barefoot, B.O. (2004). Higher education's revolving door: Confronting the problem of student drop out in US colleges and universities. Open Learning: The Journal of Open, Distance and e-Learning, 19(1). 9-18. https://doi.org/10.1080/0268051042000177818

Crisp, G., \& Taggart, A. (2013). Community college student success programs: A synthesis, critique, and research agenda. Community College Journal of Research and Practice, $37(2)$, 114-130. https://doi.org/10.1080/10668920903381847

Dewey, J. (1916). Democracy and education: An introduction to the philosophy of education. New York: Macmillan.

Eckton, D. R., \& Palfreyman, S. R. (2017). Self-directed learning as a form of self-leadership: An exploratory study in a first-year experience student success course. The Journal of Student Leadership, 1(2), 15-29.

Hankin, J. N. (1996). The community college: Opportunity and access for America's first-year students. National Resource Center for the Freshman Year Experience \& Students in Transition, University of South Carolina. Retrieved from https://files.eric.ed.gov/fulltext/ED393486.pdf

Hoops, L. D., \& Artip, A. (2016). College student success course takers' perceptions of college student effectiveness. Learning Assistance Review, 21 (2), 55$67 . \quad$ Retrieved from https://files.eric.ed.gov/fulltext/EJ1114471.pdf

Johnson, E. B. (2002). Contextual teaching and learning: What it is and why it's here to stay. Thousand Oaks, CA: Corwin Press, INC.

Karp, M. M., \& Bork, R. H. (2014). “They never told me what to expect, so I didn't know what to do": Defining and clarifying the role of a community college student. Teachers College Record, 116(5), 1-40.

Karp, M. M., Raufman, J., Efthimiou, C., \& Ritze, N. (2017). Revising a College 101 course for sustained impact: Early outcomes. Community College Journal of Research and Practice, 41(1), 42-55. https://dx.doi.org/10.1080/10668926.2016.115292 $\underline{9}$

Kimbark, K., Peters, M. L., \& Richardson, T. (2017). Effectiveness of the student success course on persistence, retention, academic achievement, and student engagement. Community College Journal of Research and Practice, 41(2), 124-138. https://doi.org/10.1080/10668926.2016.1166352

O'Gara, L., Karp, M. M., \& Hughes, K. L. (2009). Student success courses in the community college. Community College Review, 36(3), 195-218. https://doi.org/10.1177/0091552112472227

Shapiro, D., Dundar, A., Huie, F., Wakhungu, P.K., Yuan, X., Nathan, A., \& Bhimdiwali, A. (2017). Completing college: A national view of student completion rates Fall 2011 Cohort (Signature Report No. 14). Herndon, VA: National Student Clearinghouse Research Center Retrieved from https://nscresearchcenter.org/wpcontent/uploads/SignatureReport14 Final.pdf

Stupka, E. (1993). An evaluation of the short term and long term impact a student success course has on academic performance and persistence. Sacramento, CA: Sacramento City College. Retrieved from https://eric.ed.gov/?id=EJ1114471.

Tinto, V. (2012). Completing college: Rethinking institutional action. Chicago, Illinois: University of Chicago Press.

Tinto, V. (2017). Reflections on student persistence. Student $\begin{array}{lll}\text { Success. } & 8(2), & 1-8\end{array}$ https://doi.org/10.5204/ssj.v8i2.376.

Wiseley, W. C. (2009). Effectiveness of contextual approaches to developmental math in California community colleges. (Doctoral dissertation) University of the Pacific, Stockton, United States. Retrieved from https://scholarlycommons.pacific.edu/uop_etds/24 $\underline{01 /}$

Zalaznick, M. (2016). Student success initiatives front and center. University Business, 19(1), 40. Retrieved from https://www.universitybusiness.com/article/outloo k-student-success-blending-academics-and-lifelessons 